\title{
Substantial and significant pits in the Mesolithic of Britain and adjacent regions
}

\author{
Joshua Pollard
}

c.j.pollard@soton.ac.uk

Department of Archaeology, University of Southampton, Highfield, Southampton, SO17 1BJ, UK)

\begin{abstract}
This paper describes a series of substantial pits of Mesolithic date, notable for their complex fill and recutting sequences, association with burnt and transformed materials, occasional linear arrangement, and connection to the observation of celestial phenomena. While likely tied into regular rounds of movement, it is argued they represent reserved and sacred places where special activities were undertaken which connected cosmic forces.
\end{abstract}

\section{Keywords}

Mesolithic, pits, alignments, cosmology

\section{Mesolithic 'monuments' and landscape markers}

A remarkable record of monument building is associated with earliest (Neolithic) farming communities of Atlantic and Northern Europe, comprising a range of earthen and megalithic tombs, enclosures and menhirs (Scarre 2002; Bradley 2007; Cummings 2008). In contrast, ceremonial architecture belonging to post-glacial (Mesolithic) hunter-gatherers within these regions is slight, or, regionally, non-existent. Cummings and Harris rightly observe that 'the monuments constructed in the Neolithic are, without question, something very new' (2014:832). Notwithstanding these very real differences in the record for the two periods, evidence for Mesolithic monumentality has been posited, and deployed to shape narratives of the period which move beyond a long-standing focus on matters economic (eg Pollard 1990; Cummings 2000; Allen \& Gardiner 2002; Blinkhorn \& Little in press). At best, any definition of what constitutes a 'monument' or something 'monumental' will be loosely defined, but the terms evoke physical constructs, either humanly-made or natural, that possess size and durability, serve to commemorate or memorialise, and which may afford settings/spaces through which the living can intercede with ancestral and/or supernatural domains (Bradley 1993; Scarre 2011). Conneller (2011) cites examples of Mesolithic wooden landscape markers, middens and natural places as features that might be described as monuments. They can certainly be accommodated within broad definitions of monumentality that focus on scale, endurance and commemoration; though critique has been levelled at the interpretation of midden sites as monuments akin to later chambered tombs (eg Pollard 1990), not least because of their reading as such in relation to Neolithic frames of reference (Finlayson 2006; Warren 2007). Equally, one might see large circular houses of 9 th to early 7 th millennia cal BC date from northern Britain and Ireland, such as those at Howick, Northumberland (Waddington 2007), Echline Fields, in the Forth estuary (Robertson et al 2013), and Mount Sandel in Northern Ireland (Woodman 1985; Bayliss \& Woodman 2009), as monumental in quality. Warren, for example, considers their extrahabitational role as enduring places which fostered common traditions, hospitality and connection (Warren 2015).

Rather than being overly constrained by the monument label and its definitional boundaries and connotations, there is mileage in thinking through the different ways post-glacial hunter-gatherers transformed places through digging, building, altering environments, and significant engagements with the substances and materials of landscapes (Blinkhorn \& Little in press). In this respect, the focus might shift to the form and context of those practices, and their connections, effects and 
legacies, intended or otherwise, working across a range of scales and significances (cf. McFadyen 2006a). Within such a framework, we might focus on how places became invested with significance, narrative qualities, association and sacredness through the repetition of quite routine and smallscale acts: that might occur through repeated extraction of stone, return to a campsite, or maintaining a clearing, for example. A monumental perspective will often focus on the scale of an act, its demanding effort, and draw upon resources, and what McFadyen (2006b) has described as 'quick architecture' - a planned build. In contrast, for hunter-gatherer worlds we should consider how the affective qualities linked to traditional kinds of monumentality, such as evocation, memory work and presencing of the numinous, can accrue around places and features, both humanly-made and natural, over time and via patterns of routine engagement. In other words, those places and features might take on the quality of the monumental even though that was never conceived at the outset. Such a perspective has resonance with Ingold's notion of taskscape and dwelling perspective (Ingold 1993; 2000) since it recognises the emergent properties of places and things that arise through the project of living. With attention to such emergent qualities of place and practice, here the significance of cumulative acts of gathering, pit digging, burning and filling in the Mesolithic of Britain and northern France are considered. The subject is a series of distinctive large pits clustered into groups and linear arrangements, which it is argued served as important and long-lived ceremonial foci.

\section{Pits and substantial pits}

Largely through developer-led excavation, and more systematic sampling for charred plant remains and application of radiocarbon dating, Mesolithic pits are now recognised as an increasingly significant element of the record for the period (Lawton-Matthews \& Warren 2015; Blinkhorn et al in press). With a wide chronological currency, they occur singly and in groups, and there is much variation in size, form, filling and likely function; a number containing seemingly placed deposits of artefacts (ibid.; Blinkhorn \& Little in press). Pit digging and filling is therefore best viewed as a technology employed with a variety of intentions, in a range of contexts linked both to places of habitation and other practices, rather than one coherent practice.

In this paper it is proposed that a number of these features can be isolated from the rest by virtue of their substantial size (generally in excess of $1 \mathrm{~m}$ in diameter and $0.5 \mathrm{~m}$ in depth), complex fills, occasional grouping into linear arrangements, and virtual absence of material culture (figure 1 ). Their currency spans the 10th to 5 th millennia cal BC, seemingly with a greater frequency towards the earlier end of that range. It is inherently unlikely they served a purpose as pit-fall traps, extraction or storage features (see Murray et al 2009 for relevant discussion of those at Warren Field); and they exhibit a remarkable level of landscape persistence. Their role might be crudely glossed as 'ceremonial'. Of these, a linear arrangement adjacent to Stonehenge in Wiltshire, southern England - among the first to be recognised - has regularly featured in the literature as precociously early evidence of monumental expression (eg Allen \& Gardiner 2002; Darvill 2006, 62; Parker Pearson 2012:135-7). Critical to understanding of their function is a correct reading of their form. They, like several others, have for some time now been regarded as pits for large marker posts, but as argued below, this may well be erroneous. Post settings of the period are known (eg that marking an $8^{\text {th }}$ millennium BC cremation burial at Hermitage, Ireland: Collins 2009; Little et al 2017), but they may be less common than currently envisaged.

\subsection{Deconstructing Stonehenge's Mesolithic 'totem poles'}

This account begins with the Stonehenge pits (figure 2). They comprise an east-west line of three large pits (Pits A-C) and a probable tree-throw hollow, discovered c. $250 \mathrm{~m}$ to the NW of Stonehenge in 1966 when a visitor car park was being extended. A fourth pit of comparable form (Pit 9580) was 
excavated in $1988,100 \mathrm{~m}$ to the ESE, though slightly off the alignment of Pits A-C (Vatcher \& Vatcher 1973; Allen 1995). There is a strong possibility that others may exist. A GPR survey revealed two features of comparable proportions and on a similar east-west alignment $100 \mathrm{~m}$ to the south (Bowden et al 2015:15), though they remain unexcavated. Each pit was conical in profile, with a flat base, between $1.5-2.0 \mathrm{~m}$ wide and c.1.3m deep. The 1966 pits were initially considered to be Neolithic and linked to the stone monument, though the presence of pine charcoal within them was at odds with the range of tree species growing in a predicted Sub-Boreal woodland. Subsequent radiocarbon dates provided ranges of $8820-7730 \mathrm{cal} \mathrm{BC}$ and $7480-6590 \mathrm{cal} B C$ ( $P$ its A and B), and 8090-7580 cal BC and 7700-7420 cal BC (pit 9580: Allen \& Gardiner 2002, table 10.1), placing them firmly in the Mesolithic. The timespan is long and could accommodate a model in which the features were dug at intervals. At face-value, dates from pit A mark it out as the earliest (table 1), though caution needs to be taken because of the potential for samples to be dating heartwood rather than outer growth-rings or sapwood.

No artefacts were associated with the pits and it was difficult to ascribe to them a 'functional' role. The Vatchers, who excavated Pits A to C, were confident they were post-holes, since their fills comprised outer rings of chalk rubble and cores of darker soil. Within the rubble were truncated lenses of soil that they considered to be traces of wooden wedges to support the posts (Vatcher \& Vatcher 1973:59). Pit 9580 was recognised to be related, but being filled with successive layers of chalk rubble and silt was not considered to be a post-hole (Allen 1995). It has been accepted since the 1973 publication that these features are holes that supported large, free-standing pine posts. Allen suggests they may 'represent some formal display such as a series of totem poles, or other possibly symbolic or ceremonial posts' (Allen 1995:56). Admittedly, any notion of the settings as totem poles forces a rather stretched and inappropriate analogy, though it is one that has stuck and captured professional and public imagination alike (see, for example, the official English Heritage website: http://www.english-heritage.org.uk/visit/places/stonehenge/history/). At the time of their dating in the mid 1990s these monumental markers looked to occupy an isolated position on Salisbury Plain, and they appeared as a unique and remarkably early form of monumentality. There was also the issue of their close spatial relationship to Stonehenge: whether this was entirely coincidental, even with a five thousand year gap between the two sites. Since then, evidence has come to light of contemporary activity in the local landscape. Most significant is the discovery of an exceptionally long-lived, if seasonally-occupied, habitation area on the banks of the River Avon at Blick Mead, c.3km to the east (Jacques \& Phillips 2014). Dates on butchered animal bone give a range spanning 7596-4246 cal BC, overlapping at the top end with those from the Stonehenge features. Earlier Mesolithic flintwork has been recovered $400 \mathrm{~m}$ to the west of Stonehenge (Parker Pearson 2012:236), while pine charcoal residual within a bluestone hole within Stonehenge has returned a date of 7330-7070 cal BC (Darvill \& Wainwright 2009:12).

The enigma of the coincident siting of the Mesolithic pits adjacent to Europe's most preeminent Neolithic monument may have been resolved through investigation in 2008 of Stonehenge's earthwork Avenue, which, leading to the main entrance of the henge, continues an alignment on the main midsummer sunrise - midwinter sunset solstitial axis. The Avenue was found to be in large part a natural feature, formed of three ridges of hard chalk that had differentially weathered and concentrated cryoturbation features within them. It had been minimally modified during the Neolithic through the construction of shallow ditches and banks (Allen et al 2016). A fluke of geology, these solstitially-aligned ridges were visible throughout the early-mid Holocene in conditions of open or partial woodland and grassland (Allen 1995; French et al 2012). They clearly attracted the attention of Middle Neolithic communities who recognised their connection to the movement of the sun, and monumentalised this location through the construction of Stonehenge. Their presence and recognised solstitial alignment could equally explain the siting of the Mesolithic pits, located just 200-350m to the west and set broadly in line with the north-east end of the ridges. 
Account should also be taken of other unusual geological features here which would have combined to mark out this locale as one that was highly distinctive. The ridges are 'bracketed' by natural mounds, one now incorporated in the SE sector of Stonehenge's rings, the other (Newall's Mound) c. $300 \mathrm{~m}$ to the NE; and there was likely a localised concentration of sarsen stones here (Field et al 2014:5-8). Sarsen is its itself uncommon in this landscape. The considerable cosmological and cosmogenic significance that can be attached to natural features by both hunter-gatherers and farmers alike is well attested (Carmichael et al 1994; Bradley 2000). We can of course never be certain that such significance attached to this place at this time, but it would not be unreasonable to suggest that the combination of distinctive geological features here - solstitially-aligned ridges, mounds and stones - conferred not just a sense of place to this locale, but facilitated an understanding of it as cosmologically-charged, even resonant with spiritual agency.

The choice of location for these features may therefore be explained by the unusual set of natural features present on this part of Salisbury Plain. It follows that we must understand the Mesolithic pits as components of this complex; but quite what the creation of these features was intended to achieve takes us back to questions of their form. Pits A-C at least are commonly understood to be post-holes, yet scrutiny of their forms and fills suggests they never held posts. It was the combination of dark soil cores, chalk rubble outer fills and large quantities of pine charcoal that led the Vatchers to conclude that these pits held posts (Vatcher \& Vatcher 1973). That interpretation was picked-up in the 1995 publication on 20th-century excavations at Stonehenge, and has stuck. However, the morphology of the features and a close reading of their fills supports an alternative view that these are pits with complex staged fills and recuts which never held timbers (figure 2).

First, the slightly weathered, splayed, upper profiles to the pits shows they were left open for a period of time before being fully filled. Second, the chalk rubble in all is interdigitated with occasional lenses of soil/silt (the Vatchers' 'wedges'), which could indicate temporary stabilisation and staged backfilling. It is certainly not the clean chalk rubble packing one would expect with postholes and does not match that of large later Neolithic post-holes at nearby sites such as Durrington Walls (Wainwright \& Longworth 1971). Critically, the 'post-pipes', which do not extend to the bases of the features, as would be usual, are not straight-sided, but conical, markedly so in the case of Pit C, while that of A has a splayed upper profile. Pit 9580 was reported as similar in morphology but different in fill (and purpose) to Pits A-C. However the published section of the feature shows successive layers of silt and chalk rubble which match those in Pits A-C, and a dark soil filled conical 'core' (deposit 9585) that, while shallower, looks equivalent to those in the Vatcher pits (Allen 1995:fig. 28). A more critical reading of the fills leads to the conclusion that these were deep pits dug then filled, perhaps through a combination of weathering and partial backfilling (note the presence of charcoal rich layers and lenses, on the very base in the case of Pit C: figure 2). They were then recut, and those recuts filled with more humic soil. In the case of Pit $\mathrm{C}$ at least two episodes of within-fill recutting can be discerned, while the stepped lower profiles to this and pit 9580 are highly suggestive of major phases of recutting that largely reworked these features. Throughout the fill sequence charcoal-rich soils continued to accumulate, one such lens being present with the recut 'core' of Pit A (Vatcher \& Vatcher 1973:59).

The detail of this account is important, since it bears on any interpretation of what these features were and how they 'performed'. Rather than acting as containers for 'marker' posts, or decorated timbers, or some form of wooden structural setting, they can instead be seen as pits which were the focus for repeated returns and intervention (i.e. filling, recutting). They may not have been particularly visible, although mounds of up-cast from their digging perhaps remained for some considerable time, and their presence could too register through differential vegetation growth (Garrow et al 2005, 155). These were not posts pointing to the sky, but holes that penetrated the earth. Pine charcoal was present in all, and in some quantity, indicating the presence of fires close 
by. With the exception of tiny fragments of burnt bone, unfortunately not identified to species (Vatcher \& Vatcher 1973:59, 61), artefacts were absent.

\subsection{Substantial pits beyond Stonehenge}

Subsequent to the dating of the Stonehenge pits, features of comparable form and date have been identified in other locations in Britain and northern France (Allen \& Gardiner 2002; Mercer \& Healy 2008; Murray et al 2009; Achard-Corompt 2015). They include two, possibly four, pits of late 9th to late 8th millennium BC date on the west-facing slope of Hambledon Hill in Dorset, c. $45 \mathrm{~km} \mathrm{SW}$ of Stonehenge. The northernmost, WOWK3 F4, is relatively modest in size. F279 is heavily truncated and originally very substantial (originally c. $2 \mathrm{~m}$ wide and over $1 \mathrm{~m}$ deep), with complex fills and recuts. Both included deposits of pine charcoal. The location here is dramatic, marking the transition from the high ground of the Wessex chalk to the clay and sandstones to the west; and looking out across the headwaters of the River Stour which affords a major routeway connecting the south coast and Somerset Levels (Mercer \& Healy 2008:43-8). Occupying a similar scarp location on the western edge of the chalk of Salisbury Plain is a recently excavated pit on Urchfont Hill, $15 \mathrm{~km}$ to the NW of Stonehenge (Roberts et al 2017). Published details provide little indication of form, beyond in being sub-circular and possibly re-cut. Pine charcoal, some burnt bone, burnt flint and tiny amounts of microdebitage were present in the fills. Three dates on charcoal all group in second half of 8th millennium cal BC (table 1), overlapping with pits B and 9580 at Stonehenge and F279 on Hambledon Hill. The Urchfont pit is recorded as cutting a length of ditch, which was not excavated; however, its stratigraphic position means it too must be Mesolithic. Another section of Mesolithic ditch is known only $4 \mathrm{~km}$ to the SW on Strawberry Hill, West Lavington, here sealed under colluvium, and dated to 8930-8080 cal BC (Allen \& Gardiner 2002:148). Seemingly without parallel, it is unfortunate that nothing is known of the extent and function of these early linears, particularly since they may possess a connection to the kinds of pits considered here.

The geographic spread of these substantial pits is extensive. Most remarkable, and lying at the southerly edge of their currently recorded distribution, is the recent discovery through large-scale excavation of over 200 large, vertically-sided, pits at Recy/Saint-Martin-sur-le-Pré, Picardy, Northern France (Achard-Corompt 2015). These are set in crude alignments that extend over a distance of at least $1 \mathrm{~km}$, parallel to the River Marne. Several have been dated to 9200 and $7540 \mathrm{cal}$ BC. Again, they are unassociated with contemporary material culture, and include deposits of carbonised material. A number appear to preserve traces of 'post-like' settings in their base (perhaps small recuts). Further pits, this time with a Y-shaped profile ('Schlitzgruben': Achard-Corompt et al 2011), were created across the same zone during the Neolithic. Comparable features of 10th to 6th millennium cal BC date have come to light through recent work on other sites in the Champagne region (Philippe De Smedt pers. comm.), suggesting a sustained tradition of creating substantial pits over the longue durée.

Normally devoid of material culture, substantial pits of this kind are only recognised as of Boreal age because of the presence of pine charcoal which has been subsequently radiometrically dated. With more routinized application of radiocarbon dating their frequency is only likely to increase; and a better sample of such features will undoubtedly assist in understanding their role. Considerable insight has, however, already been afforded through work on a late 9th to early 7th millennium BC pit alignment excavated at Warren Field, Crathes, Aberdeenshire, Scotland (Murray et al 2009). Discovered after the publication of the Stonehenge pits, this represents the most systematically investigated and reported Mesolithic pit group from the British Isles (figure 3). Radiocarbon dates within a range from 8210 to $6690 \mathrm{cal} \mathrm{BC}$ (table 1) show that it is broadly contemporary with that at Stonehenge. Furthermore, both comprise alignments, and share common complexity in their fills. Located close to the River Dee, the Warren Field alignment comprises a slightly irregular line of 
perhaps 17 pits running over a distance of c.90m. Dug into hard gravels, the alignment runs NE-SW along the top of a low ridge. Twelve of the group were excavated and found to be circular or oval, between 1.0 to $2.6 \mathrm{~m}$ in diameter and 0.55 to $1.3 \mathrm{~m}$ deep (Murray et al 2009). A lack of overlap in the dates from different pits - eg Pits 6, 18 and 19 (8210-7620 cal BC), and 16 (7600-7480 cal BC), and 5 (7290-6690 cal BC) - implies they were not all dug at once, although there must be a possibility that recutting may have truncated the earliest cuts and fills in some instances. The span of dates nonetheless demonstrates longevity and on-going human presence at this locale over several centuries. At least two of these pits were redefined through shallow recuts during the terminal Mesolithic or earlier Neolithic (latest 5 th to early $4^{\text {th }}$ millennium BC), likely just before the construction of a large timber hall (ibid.).

Following a now familiar pattern, the pits contained deposits of charcoal (in this case hazel/alder, birch and willow/poplar), sometimes deposited on the base of the pits. Their fills were complex, consisting of layers of gravels and sands with lenses of charcoal-rich soil, and upper recuts filled with silty soils. Pit 19 included a basal deposit of charcoal and blackened pebbles, and tiny amounts of burnt bone; while in Pit 18 a large stone covered a charcoal-rich deposit containing hazel, birch and alder. Fill processes are likely to result from both human agency (digging, deposition of soils and charcoal, and recutting) and natural processes (weathering and periodic stabilisation)(Murray et al 2009). Charcoal in their fills could derive from fires on adjacent surfaces (ibid., 13). The only artefacts from Mesolithic contexts were three flint flakes, a blade, and a piece of burnt flint. What the fill complexity highlights most is that the pits were dynamic entities, periodically reengaged with.

Most remarkable, chemical analysis of soil samples from pits 5, 6 and 16 showed enhanced levels of metals (copper, lead and silver) in some of the fills, especially those that were charcoal-rich. Given the pits pre-date the appearance of metallurgy in NW Europe by several millennia (the accepted date of introduction for copper and gold metallurgy in Britain is c.2450/2400 cal BC: Needham 2012), the excavators suggest the elements were introduced in the form of crushed rock, and that a possible source for these rocks is a point $40 \mathrm{~km}$ west on the River Dee at the Pass of Ballater. The latter is a dramatic landmark marked by rocks of 'quite vivid purples and greens which might have attracted prehistoric people' (ibid., 14). Together with the presence of alder and willow charcoal, which was likely gathered from elsewhere since it is not registered in the pollen record from the site (ibid.:27; and Lancaster in Murray et al 2009:19), there is evidence of significant materials being gathered, brought in, transformed in various ways (crushing, burning), and conceivably deliberately mixed with soils that either accumulated around the pits or were intentionally deposited within them.

There is further 'depth' and unanticipated complexity to these features. In a recent reinterpretation, Gaffney et al. (2013) propose that the alignment 'appears to possess basic calendrical functions', appearing 'to mimic the phases of the Moon' and aligning on a prominent topographic point (the low hills of Cairn-Mon-Earn and Craigberg) where the sun is seen to rise on the midwinter solstice. The notion it was created to track time and so assist in the scheduling of productive activities seems overcomplicated, since there are many ways time reckoning could be achieved without creating a setting of this kind. But the basic alignments and explicit referencing of the winter solstice seem to stand scrutiny. Gaffney et al note the presence of two similar pit alignments, known from aerial photographs but currently undated, within $80 \mathrm{~km}$ of Warren Field at Balendoch and Arrat. They occupy similar landscape settings on the Rivers Isla and South Esk, and on routes into uplands. Again, they have modelled alignments on the midwinter solstice sunrise (Gaffney et al 2013). Although there is no direct evidence for such a solstitial axis being incorporated in the laying out of the Stonehenge pit line, its position close to the solstice-aligned chalk ridges and periglacial stripes that later formed the Avenue provides evidence for similar concerns to link to features understood to have a connection with major astronomical phenomena. 


\section{Discussion}

The features described here are related by their substantial form, complex fill sequences with indications of periodic recutting, presence of charcoal, sometimes calcined bone, occasional linear arrangement and connection to the observation of celestial phenomena. Their fills are virtually free of contemporary material culture, and they are frequently sited in significant landscape locations. Such characteristics set them apart from other forms of pit digging undertaken during the period (e.g. those linked to houses at Echline Fields on the Forth estuary, Scotland (Robertson et al 2013), and Mount Sandel, Coleraine, Northern Ireland (Woodman 1985)). The majority date to the 9 th to mid-7th millennia cal BC; although potential for a much longer chronology is hinted at by a 5th millennium BC example displaying similar features to those described at Spurryhillock, Aberdeenshire (Alexander 1997)(table 1). If their occurrence is more heavily weighted towards the earlier part of that span their predominant currency falls within the same horizon as large circular houses and corporate cemeteries (Cauwe 2001; Schulting 2005; Conneller 2006; Bayliss \& Woodman 2009; Robertson et al 2013). There is a certain scale to activity and commitment to 'making place' that unites these different practices.

As reinterpretation of Stonehenge pits has highlighted, it is important to play close scrutiny to form and fills. The Stonehenge pits were not post-holes, and so could not have performed as landscape or 'cultural' markers as commonly perceived (eg Allen \& Gardiner 2002). Recognising this forces us to concentrate instead on aspects such as the repeated intervention and reinstatement displayed in processes of recutting, and on the status of the deposits of burnt material routinely encountered in their fills. Pit 5 at Warren Field provides suitable illustration and a departure point for reflection. Few of the layer boundaries display the 'flattening-out' towards the top of the feature expected through natural infill. In fact, there may be at least eight episodes of recutting here (Murray et al 2009, fig. 5). Dates on charcoal show that both burning of wood and recutting occurred during the late 8th to early 7 th millennia, again during the 6th millennium, and finally during the latest 5 th to early 4 th millennia cal BC. The longevity of recognition and intervention is striking, but is reflected too in the fill and recut sequence for Pit 9580 at Stonehenge (Allen 1995). It is only by obtaining sufficient sequences of dates, rather than determinations that just target start dates, that such detail comes to light.

Where does this leave interpretation, especially since analogies are hard to come by? They likely represent a unique if persistent form of practice that needs to be understood on its own terms. Transformation of both place and substance is inferred. Wood was burnt, occasionally at very high temperatures (Campbell, in Roberts et al 2017) and this, along with other materials such as burnt/crushed rock and bone, worked into the fills, either through direct deposition or weathering in from surfaces immediately around these pits. Tiny quantities of calcined bone are known from the Urchfont Hill, Stonehenge and Warren Fields pits, but none has been identified to species. Conceivably it may be human (cremations are known from the period: Little et al. 2017), and could suggest a recurrent connection between these places and mortuary rites.

Accepting the likelihood of an animate ontology (Guenther 1999; Alberti \& Bray 2009), these substances and even the pits themselves need not be viewed as inert, but rather as significant actants in practices that combined people, place, geology, celestial bodies and other entities (e.g. the trees from which charcoal came) in relational engagements that served to enable the flow of forces that reproduced and revitalised the world. That world was perhaps understood as being composed of tiered domains - an underworld, surface and sky - in which acts of exchange and reciprocity with the earth ensured cosmic balance and communication with spirits (Zvelebil 2003, 2008). Digging and recutting pits connected people to the underworld and one domain of spirits; the 
incorporation of celestial alignments - pulling in the sky - and the smoke that rose from the burning of fires (the residue of which entered the pits as charcoal) facilitated intervention in another spiritual domain. Underworld, surface and sky were drawn together in potent, regenerative acts that reproduced the order of the world.

In discussing the Warren Field alignment, Murray et al suggested the site was 'visited only occasionally, or by a restricted number of people' (Murray et al 2009:27); effectively, that it was a 'taboo' space where important interventions into other worlds took place that were guided over by initiated individuals. Certainly the absence of worked flint and unburnt animal bone from the fills of these and other pits described here implies they were not sited in the same locations where knapping, butchery or food consumption took place. This need not, however, imply they were visited infrequently: after all, the repeated recutting of many stands as a measure of repeated return and human presence. Yet, they may well have occupied and served to reinforce places that were regarded as sacred, and so set with prohibitions on who could visit, and when. Perhaps time scheduling is indicated by the claimed solstitial connections of sites like Warren Field? Their creation, reinstatement and visitation might be bound into regular cycles of movement and resource procurement. But we should not fall back into a pattern of privileging subsistence routines over the demands of dealing with spirits, ancestors and sacred forces. As David et al note, one of the most important motivations for hunter-gatherers to visit places is to pay observance to spiritual/ritual demands (David et al 2014, 1178-9; see to McNiven 2003). Rather than peripheral and marginal places, pit sites could have occupied very central positions in landscapes of movement and inhabitation.

A final observation relates to the potential extent of some of these sites. Only at Recy/Saint-Martinsur-le-Pré has excavation of any scale been linked to the investigation of such pits. Here it revealed vast numbers, loosely distributed with gaps between clusters, but occupying an area at least $1 \mathrm{~km}$ in length. Could that be true of others? Are we missing 'big sites' through small interventions, and so not appreciating the landscape-scale of these significant locales? At Hambledon Hill the Mesolithic pits were picked up in trenches $200 \mathrm{~mm}$ apart; while those on Urchfont Hill and Strawberry Hill were revealed through two small archaeological interventions set $4 \mathrm{~km}$ apart along the same chalk ridge. Geophysical survey hints at further Mesolithic pits at Stonehenge, but widely spaced in relation to those already known. If we think of these various interventions as akin to exercises in sampling, and acknowledge the high 'hit rate' of discovery, logic would dictate that many more of these features are present in these locations. Recy/Saint-Martin-sur-le-Pré may not be unique.

\section{Acknowledgements}

I would like to thank Colin Grier and Margo Schwadron for their invitation to act as one of two discussants at the 2016 SAA session on hunter-gatherer monumentality, and so, critically, starting me to think about such matters. Graeme Warren provided invaluable help with recent relevant literature on the Mesolithic, and the three anonymous reviewers offered constructive comment. Both Colin and Graeme deserve thanks for their patience.

\section{References}

Achard-Corompt, N 2015. Premiers aperçus des fouilles archéologiques de 2013 et 2014 à Recy/Saint-Martin-sur-le-Pré (marne) 'Parc de Référence'. Bulletin de la Société Archéologique Champenoise 108(1):3-5. 
Achard-Corompt, N, Auxiette, G, Fromont, N, Ghesquière, E, Giazzon, D, Kasprzyk, M, Marcigny, C \& Riquier, V 2011. Les fosses à profil «en V-Y-W» / Schlitzgruben: retour sur une énigme. Revue Archéologique de Picardie 28(1):549-558.

Alberti, B \& Bray, TL 2009. Animating archaeology: of subjects, objects and alternative ontologies. Introduction. Cambridge Archaeological Journal 19(3):337-343.

Alexander, D 1997. Excavation of pits containing decorated Neolithic pottery and early lithic material of possible Mesolithic date at Spurryhillock, Stonehaven, Aberdeenshire. Proceedings of the Society of Antiquaries of Scotland 127:17-27.

Allen, M 1995. Before Stonehenge. In Cleal, RMJ, Walker, K \& Montague, R Stonehenge in its landscape: twentieth-century excavations. London: English Heritage:41-56.

Allen, MJ, Chan, B, Cleal, R, French, C, Marshall, P, Pollard, J, Pullen, R, Richards, C, Ruggles, C, Robinson, D, Rylatt, J, Thomas, J, Welham, K \& Parker Pearson, M 2016. Stonehenge's Avenue and Bluestonehenge. Antiquity 90:991-1008.

Allen, MJ \& Gardiner, J 2002. A sense of time: cultural markers in the Mesolithic of Southern England? In David, B \& Wilson, M (eds) Inscribed Landscapes: marking and making place. Honolulu: University of Hawai'i Press: 139-153.

Bayliss, A \& Woodman, P 2009. A New Bayesian Chronology for Mesolithic Occupation at Mount Sandel, Northern Ireland. Proceedings of the Prehistoric Society 75:101-123.

Blinkhorn, E \& Little, A In press. Being Ritual: identifying ritual behaviour within an ephemeral material record. **Venue?**

Blinkhorn, E, Lawton-Matthews, E \& Warren, G In press. Digging and filling pits in the Mesolithic of England and Ireland: comparative perspectives on a widespread practice. **Venue?**

Bowden, M, Soutar, S, Field, D \& Barber, M 2015. The Stonehenge Landscape: analysing the Stonehenge World Heritage Site. Swindon: Historic England

Bradley, R 1993. Altering the Earth: the origins of monuments in Britain and Continental Europe. Edinburgh: Society of Antiquaries of Scotland, Monograph Series Number 8.

Bradley, R 2000. An Archaeology of Natural Places. London: Routledge.

Bradley, R 2007. The Prehistory of Britain and Ireland. Cambridge: Cambridge University Press.

Bronk Ramsey, C 2009. Bayesian analysis of radiocarbon dates. Radiocarbon 51(1):337-60.

Carmichael, D, Hubert, J, Reeves, B \& Schanche, A (eds) 1994. Sacred Sites, Sacred Places. London: Routledge.

Cauwe, N 2001. Skeletons in motion, ancestors in action: Early Mesolithic collective tombs in Southern Belgium. Cambridge Archaeological Journal 11(2):147-163. 
Collins, T 2009. Hermitage, Ireland: life and death on the western edge of Europe. In McCartan, S, Schulting, R, Warren, G \& Woodman, P (eds.), Mesolithic Horizons: Papers presented at the Seventh International Conference on the Mesolithic in Europe, Belfast 2005. Oxford: Oxbow Books: 876-879.

Conneller, C 2006. Death. In Conneller, C \& Warren, G (eds), Mesolithic Britain and Ireland: New Approaches. Stroud: Tempus: 139-164.

Conneller, C 2011. The Mesolithic. In T Insoll (ed.) The Oxford Handbook of the Archaeology of Ritual and Religion. Oxford: Oxford University Press: 358-370.

Cummings, V 2000. The origins of monumentality? Mesolithic world-views of the landscape in western Britain. In Larsson, L, Kindgren, LH, Knutsson, K, Loejjler, D \& Åkerlund, A (eds), Mesolithic on the move: papers presented at the Sixth International Conference on the Mesolithic in Europe, Stockholm. Oxbow: Oxbow Books:74-81.

Cummings, V 2008. The architecture of monuments. In Pollard, J (ed.) Prehistoric Britain. Oxford: Blackwell:135-159.

Cummings, V \& Harris, O 2014. The continuity of hunting and gathering amongst farmers in prehistory in Neolithic north-west Europe. In Cummings, V, Jordan, P \& Zvelebil, M (eds), The Oxford Handbook of the Archaeology and Anthropology of Hunter-Gatherers. Oxford: Oxford University Press: 824-837.

Darvill, T 2006. Stonehenge: the biography of a landscape. Stroud: Tempus.

Darvill, T \& Wainwright, G 2009. Stonehenge Excavations 2008. Antiquaries Journal 89:1-19.

David, B, Lamb, L \& Kaiwari, J 2014. Landscapes of mobility: the flow of place. In Cummings, V, Jordan, P \& Zvelebil, M (eds), The Oxford Handbook of the Archaeology and Anthropology of HunterGatherers. Oxford: Oxford University Press: 1163-1190.

Field, D, Linford, N, Anderson-Whymark, H, Barber, M, Bowden, M, Linford, P \& Topping, P 2014. Analytical surveys of Stonehenge and its environs, 2009-2013: part 1 - landscape and earthworks. Proceedings of the Prehistoric Society 80:1-32.

Finlayson, B. 2006. Overview - setting up questions. In Conneller, C \& Warren, GM (eds) Mesolithic Britain and Ireland: new approaches. Stroud, Tempus: 165-184.

French, C, Scaife, R, Allen, MJ, Parker Pearson, M, Pollard, J, Richards, C, Thomas, J \& Welham, K 2012. Durrington Walls to West Amesbury by way of Stonehenge: a major transformation of the Holocene landscape. Antiquaries Journal 92:1-36.

Gaffney V, Fitch, S, Ramsey, E, Yorston, R, Ch'g, E, Baldwin, E, Bates, R, Gaffney, C, Ruggles, C, Sparrow, T, MacMillan, A, Cowley, D, Fraser, S, Murray, C, Murray, H, Hopla, E \& Howard, A 2013. Time and a place: a luni-solar 'time-reckoner' from 8th millennium BC Scotland. Internet Archaeology 34. http://dx.doi.org/10.11141/ia.34.1.

Garrow, D, Beadsmoore, E \& Knight, M 2005. Pit clusters and the temporality of occupation: an earlier Neolithic site at Kilverstone, Thetford, Norfolk. Proceedings of the Prehistoric Society 71:139157. 
Guenther, M 1999. From totemism to shamanism: hunter-gather contributions to world mythology and spirituality. In Lee, RB \& Daley, R (eds), The Cambridge Encyclopedia of Hunters and Gatherers. Cambridge: Cambridge University Press: 426-433.

Ingold, T 1993. The temporality of landscape. World Archaeology 25(2):152-174.

Ingold, T 2000. The Perception of the Environment: essays in livelihood, dwelling and skill. London: Routledge.

Jacques, D \& Phillips, T 2014 Mesolithic settlement near Stonehenge: excavations at Blick Mead, Vespasian's Camp, Amesbury. Wiltshire Archaeological \& Natural History Magazine 107:7-27.

Lawton-Matthews, E \& Warren, GM 2015. Pits in the Irish Mesolithic. In Bicho, N, Detry, NC, Price, TD \& Cunha, E (eds), Muge 150th: The 150th Anniversary of the Discovery of Mesolithic Shellmiddens-Volume 2. Newcastle, Cambridge Scholars Publishing: 139-152.

Little, A, van Gijn, A, Collins, T, Cooney, G, Elliott, B, Gilhooly, B, Charlton, S \& Warren, G 2017. Stone Dead: uncovering Early Mesolithic mortuary rites, Hermitage, Ireland. Cambridge Archaeological Journal 27(2):223-243.

McFadyen, L 2006a. Landscape. In Conneller, C \& Warren, GM (eds) Mesolithic Britain and Ireland: new approaches. Stroud: Tempus: 121-138.

McFadyen, L 2006b. Building technologies, quick and slow architectures and early Neolithic long barrow sites in southern Britain". Archaeological Review from Cambridge 21(1):117-134.

McNiven, I 2004. Saltwater People: spiritscapes, maritime rituals and the archaeology of Australian indigenous seascapes. World Archaeology 35(3):329-349.

Mercer, R \& Healy, F 2008. Hambledon Hill, Dorset, England. Excavation and survey of a Neolithic monument complex and its surrounding landscape. Swindon: English Heritage.

Murray, HK, Murray, JC \& Fraser, SM 2009. A Tale of the Unknown Unknowns: a Mesolithic pit alignment and a Neolithic timber hall at Warren Field, Crathes, Aberdeenshire. Oxford: Oxbow Books.

Needham, S 2012. Case and place for the British Chalcolithic. In Allen, M, Gardiner, J \& Sheridan, A (eds) Is there a British Chalcolithic? People, Place and Polity in the Late 3rd Millennium. Oxford: Oxbow Books/Prehistoric Society Research Papers: 1-26.

Parker Pearson, M.2012. Stonehenge: exploring the greatest Stone Age mystery. London: Simon \& Schuster.

Pollard, A 1990. Down through the ages: a reconsideration of the Oban cave sites. Scottish Archaeological Review 7:58-74.

Roberts, D, Moorhead, S, Robinson, P, Payne, A, Winton, H, Hembrey, N, Bishop, B, Campbell, G, Dungworth, D, Forward, A, Middleton, A, Russell, M, Timby, J, Worley, F, Carpenter, E, Edwards, Z, Linford, N, Linford, P, Vallender, J, Henry, R, Marshall, P, Reimer, P \& Russell, N 2017. Recent work on Urchfont Hill, Urchfont, Wiltshire. Wiltshire Archaeological \& Natural History Magazine 110:134-170. 
Robertson, A, Lochrie, J \& Timpany, S 2013. Built to last: Mesolithic and Neolithic settlement at two sites beside the Forth estuary, Scotland. Proceedings of the Society of Antiquaries of Scotland 143:73-136.

Scarre, C (ed.) 2002. Monuments and Landscape in Atlantic Europe. London and New York: Routledge.

Scarre, C 2011. Monumentality. In Insoll, T (ed.), The Oxford Handbook of the Archaeology of Ritual and Religion. Oxford: Oxford University Press: 9-23.

Schulting, RJ 2005. '... Pursuing a rabbit in Burrington Combe': New research on the early Mesolithic burial cave of Aveline's Hole. Proceedings of the University of Bristol Spelaeological Society 23(3):171-265.

Vatcher, L \& Vatcher, F 1973. Excavation of three post-holes in Stonehenge car park. Wiltshire Archaeological \& Natural History Magazine 68:57-63.

Waddington, C (ed.) 2007. Mesolithic settlement in the North Sea basin: A case study from Howick, North-East England. Oxford: Oxbow Books.

Wainwright, GJ \& Longworth, IH 1971. Durrington Walls: excavations 1966-1968. London: Society of Antiquaries of London.

Warren, GM 2007. Mesolithic myths. In Cummings, V \& Whittle, A (eds) Going Over: the MesolithicNeolithic transition in North-West Europe. London: British Academy/Proceedings of the British Academy 144: 311-328.

Warren, GM 2015. Britain and Ireland inside Mesolithic Europe. In Anderson-Whymark, H, Garrow, D \& Sturt, $\mathrm{F}$ (eds) Continental Connections: exploring cross-channel relationships from the Mesolithic to the Iron Age. Oxford: Oxbow Books: 43-58.

Woodman, PC 1985. Excavations at Mount Sandel, 1973-77, County Londonderry. Belfast: HMSO.

Zvelebil, M 2003. Peopling behind the lithics: social life and social conditions of Mesolithic communities in temperate Europe. In Bevan, L \& Moore, J (eds) Peopling the Mesolithic in a Northern Environment. Oxford: British Archaeological Reports: 1-26.

Zvelebil, M 2008. Innovating hunter-gatherers: the Mesolithic of the Baltic. In Bailey, G \& Spikins, P (eds) Mesolithic Europe. Cambridge: Cambridge University Press: 18-59. 


\section{Caption list}

Figure 1. Location of key sites mentioned in text.

Figure 2. Plan and selected sections of the Stonehenge pits (after Vatcher \& Vatcher 1973; Allen 1995; Bowden et al 2015).

Figure 3. The Warren Field alignment (after Murray et al 2009 and Gaffney et al 2013). 

Table

\begin{tabular}{|c|c|c|c|c|}
\hline Lab no. & Context & Sample & $\begin{array}{l}\text { Radiocarbon } \\
\text { age (BP) }\end{array}$ & $\begin{array}{l}\text { Calibrated date }(95 \% \\
\text { confidence) }\end{array}$ \\
\hline \multicolumn{5}{|l|}{ Stonehenge } \\
\hline HAR-455 & Pit $A$ at $0.76 \mathrm{~m}$ & Charcoal: pine & $9130 \pm 180$ & $8830-7740 \mathrm{cal} \mathrm{BC}$ \\
\hline HAR-456 & Pit $B$ at $0.91 \mathrm{~m}$ & Charcoal: pine & $8090 \pm 140$ & $\begin{array}{l}7460-7390,7380-6660 \\
\text { cal BC }\end{array}$ \\
\hline OxA-4920 & $\begin{array}{l}\text { Pit } 9580 \\
\text { tertiary }\end{array}$ & Charcoal: pine & $8400 \pm 100$ & $7590-7180 \mathrm{cal} \mathrm{BC}$ \\
\hline OxA-4919 & $\begin{array}{l}\text { Pit } 9580 \\
\text { secondary }\end{array}$ & Charcoal: pine & $8520 \pm 80$ & $\begin{array}{l}7730-7450,7410-7370 \\
\text { cal BC }\end{array}$ \\
\hline Gu-5109 & $\begin{array}{l}\text { Pit } 9580 \\
\text { secondary }\end{array}$ & Charcoal: pine & $8880 \pm 120$ & $8290-7650$ cal BC \\
\hline \multicolumn{5}{|c|}{ Hambledon Hill } \\
\hline OxA-7845 & $\begin{array}{l}\text { Pit F279, } \\
\text { primary }\end{array}$ & Charcoal: pine & $8400 \pm 60$ & $7580-7340$ cal BC \\
\hline OxA-7846 & $\begin{array}{l}\text { Pit F279, } \\
\text { secondary }\end{array}$ & Charcoal: pine & $8480 \pm 45$ & 7590-7490 cal BC \\
\hline OxA-7816 & $\begin{array}{l}\text { Pit WOWK3, } \\
\text { F.42 }\end{array}$ & Charcoal: pine & $8725 \pm 55$ & 7950-7600 cal BC \\
\hline \multicolumn{5}{|l|}{ Warren Field } \\
\hline SUERC-10077 & $\begin{array}{l}\text { Primary fill pit } \\
18\end{array}$ & Charcoal: hazel & $8765 \pm 40$ & 7970-7640 cal BC \\
\hline SUERC-12262 & Early fill pit 5 & $\begin{array}{l}\text { Charcoal: birch \& } \\
\text { hazel }\end{array}$ & $8080 \pm 35$ & $\begin{array}{l}7180-7020,6960- \\
6950,6940-6920 \\
6880-6840 \text { cal BC } \\
\end{array}$ \\
\hline SUERC-12257 & $\begin{array}{l}\text { Primary fill pit } \\
5\end{array}$ & Charcoal: alder & $8100 \pm 40$ & $\begin{array}{l}7290-7270,7250- \\
7230,7190-7030, \\
6930-6920,6880-6850 \\
\text { cal BC }\end{array}$ \\
\hline SUERC-12258 & Upper fill pit 5 & Charcoal: oak & $6635 \pm 35$ & $5630-5510 \mathrm{cal} \mathrm{BC}$ \\
\hline SUERC-12259 & $\begin{array}{l}\text { Primary fill pit } \\
5\end{array}$ & Charcoal: birch & $8040 \pm 40$ & $7080-6810 \mathrm{cal} \mathrm{BC}$ \\
\hline SUERC-12260 & $\begin{array}{l}\text { Primary fill pit } \\
5\end{array}$ & $\begin{array}{l}\text { Charcoal: } \\
\text { willow/poplar }\end{array}$ & $8040 \pm 40$ & $7080-6810 \mathrm{cal} \mathrm{BC}$ \\
\hline SUERC-12261 & Final fill pit 5 & Charcoal: oak & $5170 \pm 35$ & $\begin{array}{l}4050-3940,3860-3820 \\
\text { cal BC }\end{array}$ \\
\hline SUERC-12256 & $\begin{array}{l}\text { Primary fill pit } \\
5\end{array}$ & Charcoal: alder & $7945 \pm 40$ & $7030-6690 \mathrm{cal} \mathrm{BC}$ \\
\hline SUERC-12266 & $\begin{array}{l}\text { Primary fill pit } \\
6\end{array}$ & $\begin{array}{l}\text { Charcoal: } \\
\text { willow/poplar \& } \\
\text { hazel }\end{array}$ & $8850 \pm 40$ & $\begin{array}{l}8210-7810,7810-7800 \\
\text { cal BC }\end{array}$ \\
\hline SUERC-10074 & Final fill pit 22 & Wheat & $4975 \pm 45$ & $\begin{array}{l}3940-3870,3810-3650 \\
\text { cal BC }\end{array}$ \\
\hline SUERC-10076 & $\begin{array}{l}\text { Primary fill pit } \\
22\end{array}$ & Hazelnut & $8710 \pm 40$ & $\begin{array}{l}7940-7930,7920- \\
7900,7870-7860 \\
7850-7600 \text { cal BC } \\
\end{array}$ \\
\hline SUERC-10078 & $\begin{array}{l}\text { Primary fill pit } \\
16\end{array}$ & $\begin{array}{l}\text { Charcoal: } \\
\text { alder/hazel }\end{array}$ & $8530 \pm 40$ & $7600-7530 \mathrm{cal} \mathrm{BC}$ \\
\hline
\end{tabular}




\begin{tabular}{|l|l|l|l|l|}
\hline SUERC-10082 & $\begin{array}{l}\text { Primary fill pit } \\
16\end{array}$ & Charcoal: hazel & $8460 \pm 40$ & $7580-7480$ cal BC \\
\hline SUERC-12251 & Final fill pit 5 & Charcoal: oak & $5200 \pm 35$ & $\begin{array}{l}4220-4210,4150- \\
4140,4060-3950 \text { cal } \\
\text { BC }\end{array}$ \\
\hline SUERC-4031 & Final fill pit 5 & Charcoal: oak & $5025 \pm 35$ & $3940-3710$ cal BC \\
\hline SUERC-10075 & $\begin{array}{l}\text { Primary fill pit } \\
19\end{array}$ & $\begin{array}{l}\text { Charcoal: } \\
\text { alder/hazel }\end{array}$ & $8755 \pm 40$ & $\begin{array}{l}7960-7640,7620-7610 \\
\text { cal BC }\end{array}$ \\
\hline Urchfont Hill & $\begin{array}{l}\text { Pit 92009, } \\
\text { secondary fill }\end{array}$ & Charcoal: pine & $8227 \pm 48$ & $7460-7070$ cal BC \\
\hline SUERC-26958 & $\begin{array}{l}\text { Pit 92009, } \\
\text { secondary fill }\end{array}$ & Charcoal: pine & $8210 \pm 51$ & $7450-7060$ cal BC \\
\hline SUERC-26959 & $\begin{array}{l}\text { Pit 92009, } \\
\text { secondary fill }\end{array}$ & Charcoal: pine & $8170 \pm 30$ & $7310-7060$ cal BC \\
\hline SUERC-55553 & Charcoal: oak & $5860 \pm 70$ & $\begin{array}{l}4900-4860,4860-4540 \\
\text { cal BC }\end{array}$ \\
\hline Spurryhillock & Pit 619 & Charcoal: oak & $\begin{array}{l}5700 \pm 70 \\
\text { cal BC }\end{array}$ \\
\hline Beta-73552 & Pit 619 &
\end{tabular}

Table 1. Radiocarbon dates of substantial pits (after Allen 1995; Mercer \& Healy 2008; Murray et al 2009; Roberts et al. 2017; Alexander 1997). Calibrated using OxCal 4.3 (Bronk Ramsey 2009). 


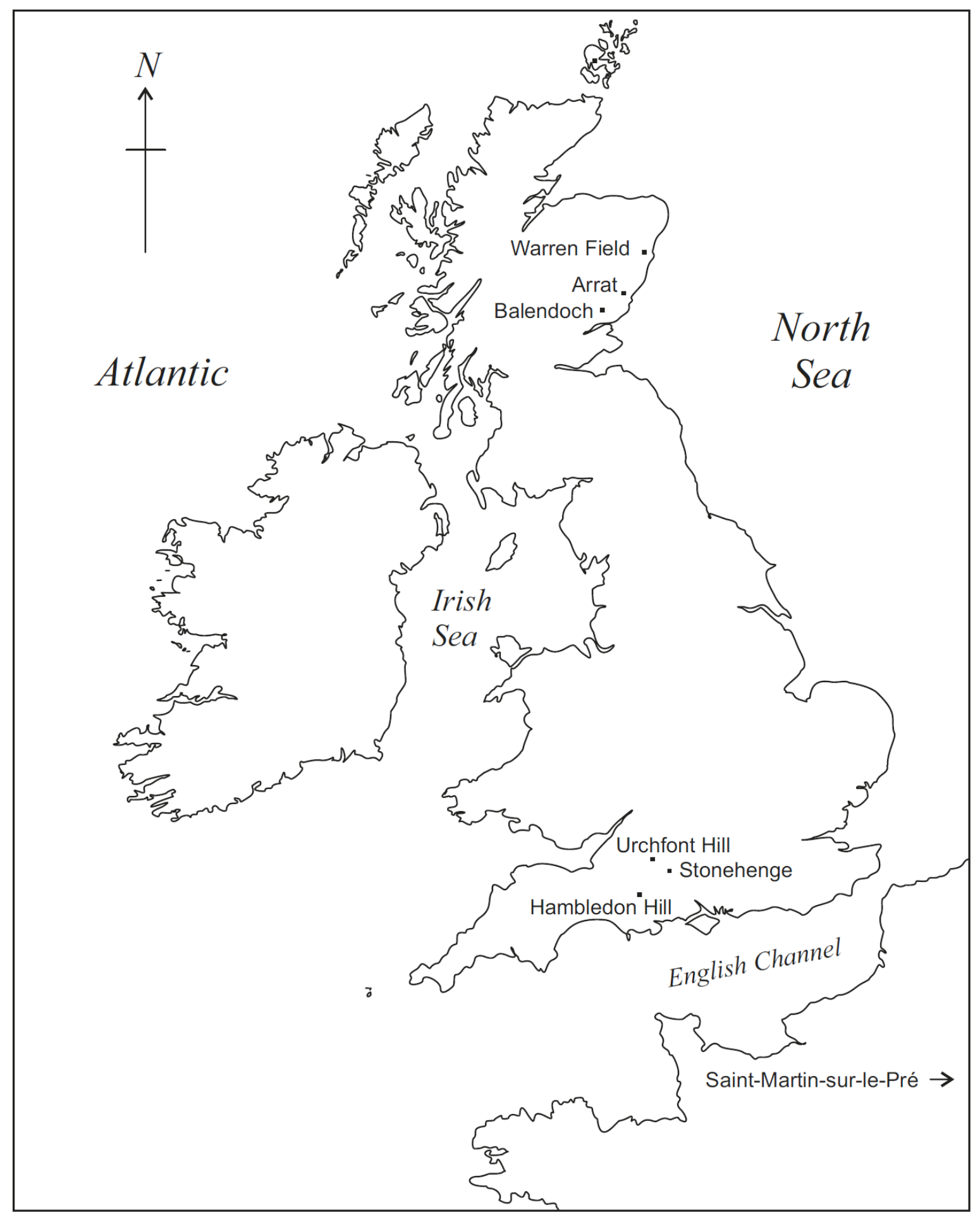

Figure 1. Location of key sites mentioned in text. 

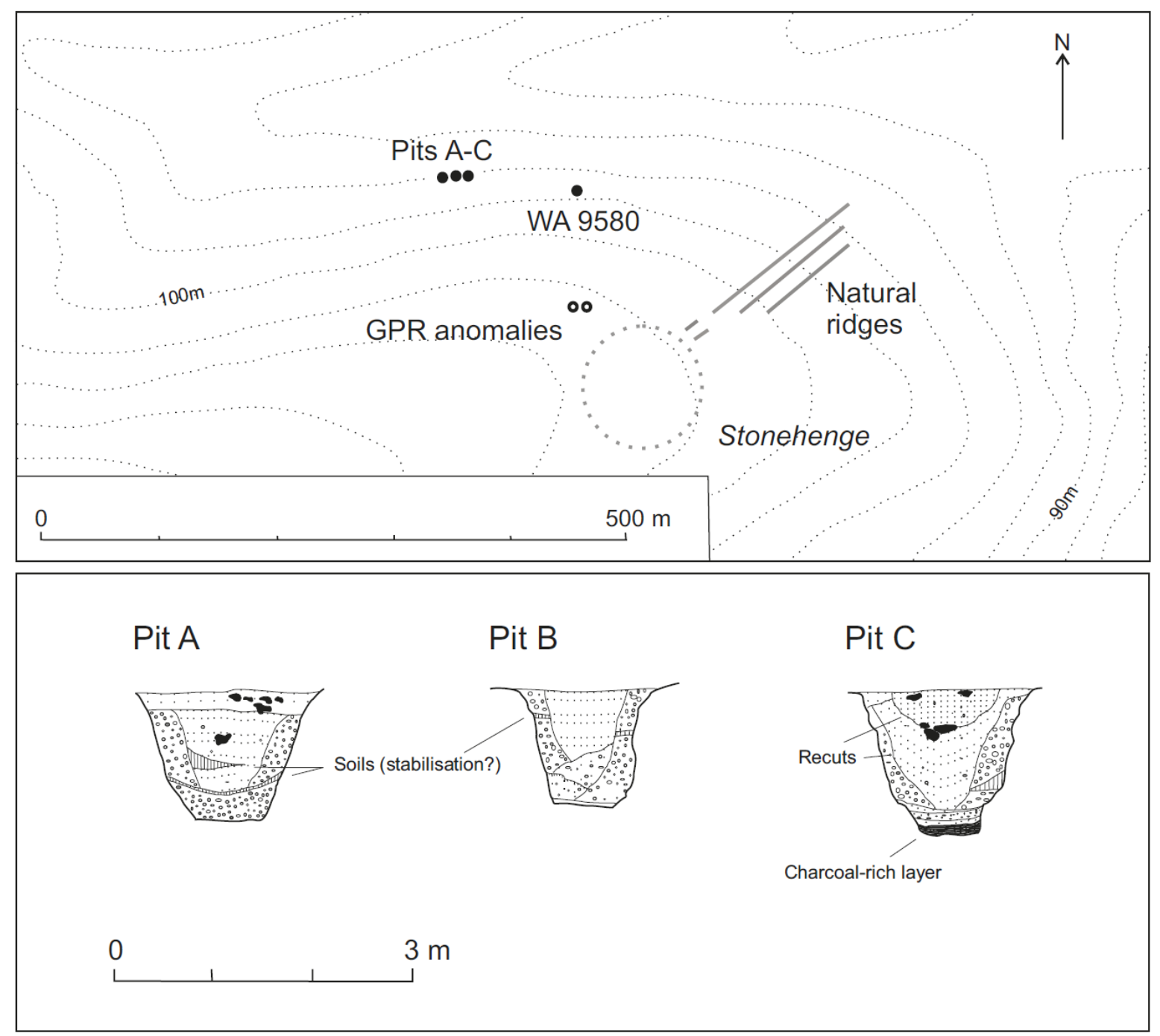

Figure 2. Plan and selected sections of the Stonehenge pits (after Vatcher \& Vatcher 1973; Allen 1995; Bowden et al 2015).

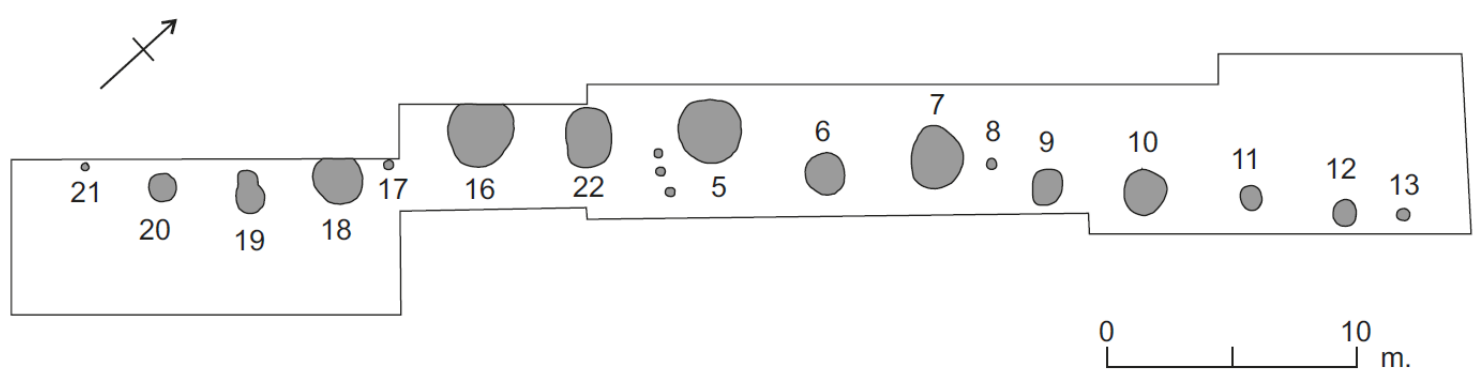

Figure 3. The Warren Field alignment (after Murray et al 2009 and Gaffney et al 2013). 